\title{
A Research on the Impact of Corporate Social Responsibility (CSR) on the Organizational Commitment of Employees in the Agro Industry
}

\author{
Vivek Nair, Ramesh Unnikrishnan, AGV Narayanan
}

\begin{abstract}
Corporate interpersonal responsibility (CSR) has been debated and practiced in one form or another for a more than 4,000 years. For instance, the historic Vedic and Sutra texts of Hinduism and the Jatakas of Buddhism consist of ethical admonitions on usury (the charging of excessive curiosity), and Islam offers a long-advocated Zakat, or an abundance taxi. The current idea of CSR could be more obviously traced to the midto-late 1800s, with industrialists like John H. Patterson of National CHECK OUT seeding the commercial welfare motion and philanthropists like John D. Rockefeller establishing a charitable precedent that was followed more than a century later with famous businessmen Bill Gates. The primary goals of the analysis are to discover the social responsibility and dedication of workers in the Agro market.
\end{abstract}

\section{INTRODUCTION}

The recent rise in CSR initiatives can be an indicator that the role of corporations in the welfare of society. In the difficult economic times, making sure a company's survival appears hard. With everything heading on, starting or maintaining solid corporate cultural responsibility (CSR) initiatives might not be near the top of a company's concern list.

When social responsibility is recognized as part of a company's business model, it can attract positive publicity, help attract and retain top talent, and improve relationships with customers and their communities. The benefits can be far and wide, including client retention, improved sales, and financial success. Do you know the great things about buying CSR? Will CSR affect employee attitudes?

Additionally, there is some proof that CSR is effective because - much like clients - CSR improves staff perceptions about the business. When an organization offers CSR initiatives, employees are even more pleased and focus on the business. CSR can help boost the worker morale in the business and create a great brand-centric corporate tradition in the business.

By producing and applying CSR initiatives, top managements experience contentment that trickles right down to their employees. It is because their exclusive identities will be partly tangled up in the firms that they function for. The workers' association with the business displays a positive attitude and feels proud to be part of the organization.

\footnotetext{
Manuscript received September 16, 2019.

Vivek Nair, Research Scholar, Karpagam Academy of Higher Education. T.N, India.

Dr. Ramesh Unnikrishnan, Research Guide and Director AICTE, Karpagam Academy of Higher Education. T.N, India.

Dr.AGV Narayanan, Research Guide and Professor, Karpagam Academy of Higher Education. T.N, India.
}

\section{Statement of the Problem}

The interest of companies to impact culture has risen in the last 3 decades. The reason behind CSR to get very much importance is that it is linked to the well-being of most stakeholders of the business. Employees choose companies that are thought to be ethical and accountable. Can the ineffective usage of Corporate Sociable Responsibility policies impact Workers' Perception towards Organizational Dedication?

\section{Significance of the Study}

The objective of the study is to analyze the impact of CSR on the organizational commitment of employees predicated on the framework produced from Social Identity Theory (SIT). An assessment of the literature reveals that SIT has a description for the hyperlink between corporate interpersonal activities and workers' attitude.

The idea proposes that folks tend to explain their selfdescriptions in an interpersonal context and classify themselves and others into diverse social categories One has a repertoire of memberships in various social categories comprising nationality, political affiliation, sport group, or similar organizations.

Social identification includes all areas of a person's selfpicture which produced from the groups each perceives himself to belong. Consequently, every membership in various social groups is a sociable identification that describes its characteristics as an associate of the group i.e., how one needs to think, experience and behave.

\section{Scope of the Study}

The analysis was conducted in Agro industry, Thiruvananthapuram. The study analyzes the relation between Corporate Social Responsibility and Employee Commitment.

The focus on corporate sociable responsibility activities create no tension among the employees. Is there a hyperlink between employee dedication and CSR initiatives by the business? We want to create a study thrust that may both unlock the mysteries of the idea of ethical tradition regarding employee determination and investigate the avenues where it impacts the staff.

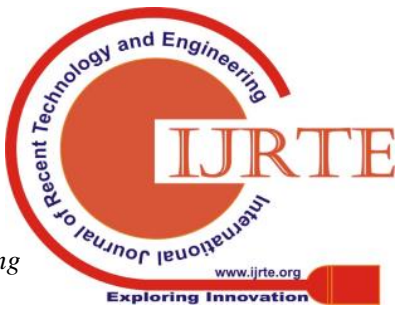




\section{A RESEARCH ON THE IMPACT OF CORPORATE SOCIAL RESPONSIBILITY (CSR) ON THE ORGANIZATIONAL COMMITMENT OF EMPLOYEES IN THE AGRO INDUSTRY}

Objectives of the Study

- To make a critical assessment of the CSR activities and their impact on the employee Commitment.

- To find out differences of opinion on CSR with respect to various demographic factors.

- To find out differences of opinion on Commitment with respect to various demographic factors.

- To find the relationship between CSR and employee commitment.

\section{Research Design}

Research could be defined as the target and systematic approach to finding the answer to an issue. Depending on data-collection, methodology provides the way to find a remedy to a particular problem. Study methodology is the idea for collecting and making use of data in order that desired information can be acquired with sufficient accuracy. It includes program-outlining, the way data are collected for evaluation that includes identifying the information-gathering strategies, the instruments to be used/ created, the way the instruments will end up being administered, and the way the details will be structured and analyzed.

\section{Collection from Secondary Sources}

In the current study company's inner records, publications, journals, websites were used as the secondary sources. Reports displaying the most recent developments and adjustments in the entire organization were used for the analysis.

\section{Collection from Primary Sources}

These date were acquired from resources like interviews with the task force, observation of the actions of the business and questionnaire for the task force.

\section{Sampling Techniques}

Sampling may be the procedure of choosing the sufficient quantity of components from the populace, thus that a report of the sample and a knowledge of its houses or qualities would allow us to generalize such real estate or attributes to the populace elements. If the information is collected just from a representative section of the universe, we state that the information is gathered by sampling. In other words, an example is usually a subset from a big populace and its research reveals the traits of the universe. There are various kinds of sampling - random sampling and non-random sampling. The foundation of random sampling is that the task of randomization shouldn't be systematic, prepared or preplanned. Random sampling is again split into straightforward random sampling, stratified sampling and cluster sampling. A non-probability sampling may be the one where the products or people included are selected without respect to the likelihood of their occurrence. It can be a straightforward technique where models of the samples will be selected based on exclusive judgment or comfort.

Here, benefit sampling can be used. Convenience sampling process is used to acquire those products/ people who are most easily available. With this technique, you can easily get a large numbers of finished questionnaires promptly and economically. There are nearly 250 employees employed in AGRO, whom 100 were chosen as sample.

\section{Tools Used}

The tool utilized by the researcher in this study was the questionnaire which was helpful in understanding the relation between CSR and worker commitment.

\section{Population}

The researcher defined the populace for the analysis as the workers in Agro industry involved with CSR initiatives.

Sampling unit: The researcher selected the organizations from Agro industry Thiruvananthapuram areas involved with CSR as the sampling device.

Sampling element: The employees in an organization involved with CSR. Sampling frame. The researcher administered questionnaires to the staff from the sampling product.

The sampling framework: it contains all personnel in Agro.

\section{Sampling Technique}

The employees gave reference of additional employees. Thus, benefits-sampling approach was also used.

Sampling size: The researcher selected the sample proportions of 100 from the employees of Agro Industry.

Tools used for this Study: 1. Chi-square test2. Correlation analysis.

\section{Limitations}

Because of inadequate time, it isn't possible to investigate all aspects highly relevant to the study. The sample includes only a share of the total number of workers employed in the company. Researcher faced difficulty in obtaining the required information. The majority of the respondents appeared to be extremely busy with their careers; they were not interested in filling the questionnaire. The reason reference is limited to TCC. The analysis was limited throughout to the day hours. So interactions with the staff members in the night shift were not possible.

\section{LITERATURE REVIEW}

Kanter (1997) asserts that for businesses to survive, they should focus on human elements. Not only the company's design, machinery, and equipment have to be up to date but, most of all, the human source of a business needs to be assessed and created at standard intervals.

Kanter (1997) argues that the ideas and equipment such as, for example, power, framework, hierarchy, ownership, and incentives which have dominated and formed our thinking must be re-examined. Therefore, it is important to really have the right type of managers to lead the business towards growth. Management of Overall performance begins with a proper vision of goals and objectives or results that require to be performed, without which it might be difficult to spotlight the actions that result in those outcomes, and all reference and attention will be spent on actions that hardly contribute to the attainment of the

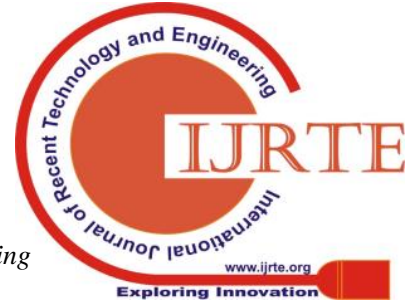


required effects. There are numerous approaches utilized by businesses to define the overall performance in an organizational context. On the other hand, Wayne et al. (2005) have explained four types of approaches predicated on competency or characteristics, task, outcomes or results and tendencies. Competency or trait-centered strategy postulates that efficiency depends upon relatively steady competencies or characteristics possessed by workforce and their overall performance is described when it comes to cognitive abilities, character traits, or competencies which are considered important for transporting out the work. This strategy is founded on the assumption that workers getting the competencies will perform greater that those that don't have those competencies or those people who are less competent.

McClelland and Boyatzis (1980) strongly support research results towards the linkage between competencies and the desired function-related behaviors. Even so, Currie and Roger (1995) say that even seemingly similar managerial jobs may vary with companies and/or circumstances. Relating to Bagchi (2010), this approach would work when the links between your duties and the outcomes possibly have a lag or perhaps there are various other reasons influencing the outcomes, which are past the worker. This approach pays to measure the managerial performances in both collection and staff features comparable to those of agencies, where a quantity of factors impacts the linkages of the responsibilities completed in the division and the organizational outcomes. Managerial performances may also be assessed predicated on the outcomes or benefits that are stated in the organization. The effect-based way neither considers the competencies or characteristics possessed by the staff nor the responsibilities that happen to be performed. Simons (2005) suggests that because of this method of work, a business has to make sure that the efficiency is associated with the option of requisite assets to attain the desired functionality and corresponding organizational help. In the emerging context, Profits on return (ROI), Administration by goal (MBO) and Wellbalanced Rating Card are several most popular ways of assessing the effectiveness at specific and organizational level (Kaplan and Norton, 1996). The evaluation of individuals with regards to behaviors that will be oriented towards the organization's goals and objectives is completed through a behavior structured approach. The assumption behind this process usually is that if the worker engages in the required behaviors, then chances are that the organizational goals and objectives will be attained. This approach could also be used to reinforce particular responses which happen to be positive and perhaps to discourage specific behaviors among the personnel, which will be disadvantageous to the business. Predicated on the evaluation of varied behaviors wanted by organizations, many authors have recognized managerial general performance behaviors that map onto broader job performance reasons such as, for example, structuring job and getting points done, contextual points comprising facilitating the mental and interpersonal contexts of 'do the job and innovative get the job done' behaviors (Organ and Ryan, 1995; Spreitzer, 1995; Podsak off et al., 2000). Although numerous studies have already been carried out by scholars across the world on isolated co-relates of managerial performance, a thorough study on conversation styles, decision producing, credibility and work tradition with regards to managerial performance is not executed in India.

Considering a manufacturing nation like India, with limited resources, the problem of managerial performance is very important. The speed of advancement would gradually decelerate if inefficient managers control institutions. Therefore, it is needed to recognize the predictors of managerial efficiency. Although all effective managers have diverse personality characteristics, there are some properties that are normal to all of them, i.e. they are successful in whatever they perform and wherever they are. Only the powerful character of a supervisor can translate his cleverness, imagination, and understanding into excellent results, thereby making him an effective manager.

YuklMcCali and Combardo (1989) proclaim that the characteristics that relate most consistently to managerial effectiveness consist of high self-confidence, strength, initiative, psychological maturity, stress, tolerance and belief through interior locus of influence, regarding interests and ideals. According with their assumption, successful managers are usually useful and result-oriented and revel in persuasive activities needing initiative and problem. Managers with great human skills can get the very best out of their persons as they understand how to connect, motivate, business lead and inspire enthusiasm and rely upon them.

Kotter (1987) have used interviews, questionnaires, archival data, \& most importantly 500 time of direct observations among 15 basic managers and discovered that the best managers spent top quality time getting together with others, through brief and disjointed conversations about careers and in addition discussed matters unrelated to results. Setting up this "network" of cooperative associations allowed these managers to influence others and apply their agendas. The partnership between managerial performance and leadership designs in 100 Indian middlelevel managers of general public sector organizations has been examined by Mathur and Yadav (1987), who discovered that managerial performance is significantly linked to subjects' leadership models. Effectiveness is especially important regarding managers because they are in charge of the overall performance of others.

According to Might and Kruger (1988), managers should abide by four concepts of empowerment viz., self-mastery, integrity, executive partnership and communication. Upon reviewing the results of 3 studies 11 programs carried out by the authors during 1983 and 1985, it is found that managerial excellence requires viewing all occasions and conditions as opportunities to see peak performance. To be able to grow from the knowledge and grasp all situations, managers should be ready to accept opinions included in this as valid and utilize it to increase their selfconsciousness and strengthen their human relationships with co-workers.

Published By:

Blue Eyes Intelligence Engineering 


\section{A RESEARCH ON THE IMPACT OF CORPORATE SOCIAL RESPONSIBILITY (CSR) ON THE ORGANIZATIONAL COMMITMENT OF EMPLOYEES IN THE AGRO INDUSTRY}

Likewise, Cangemei (1986) has referred to 21 features of very good managers, including self-confidence and understanding of one's own restrictions. According to him, good managers happen to be strongly principled, decisive and may handle tension, and intuition, and perceive errors as a way of learning. Gupta and Govindarajan (1984) collected information from 58 strategic sections which revealed that higher marketing/sales experience, better willingness to consider risk, and increased tolerance for ambiguity for the SBU basic manager contributed to effectiveness regarding "build" SBUs but hampered it regarding "harvest" SBUs. Managerial effectiveness is not an inherent level of quality and will be learnt, and perfected, with repetition. A training curriculum for interpersonal ability comprising a 4-phase unit originated for managers by Hall and Cockburn (1990) predicated on an action-learning method of skill development. Content program evaluations of system indicated that individuals at six months and 12 months demonstrated, utilizing a learner-centered modeling style that the potency of traditional administration skills training could be improved by 10 to $70 \%$. Similarly, Nwachuku (1989) discussed appropriate skill blend which appeared essential for managerial efficiency and to face the instability in organizational marketplace demand. At lower degrees of management method expertise such as for example directing, controlling and planning aren't essential, while at senior level conceptual skill is certainly most relevant. Carrying out a procedure outlined by Stewart and Stewart (1976), Hay (1992) determined 9 core qualities of good managers. These attributes were: response to improve, feeling of responsibility, effect, conceptualizing, multiple perspectives, prediction, responsiveness and respect, interacting, and self-recognition.

\section{HYPOTHESIS TESTING \& RESULTS}

Null hypothesis: There is no relation between organizational commitment and corporate social responsibility.

Null hypothesis: There is relation between organizational commitment and corporate social responsibility.

\section{Correlations}

\begin{tabular}{|c|c|c|c|c|}
\hline \multirow{2}{*}{$\begin{array}{l}\text { Spearman's } \\
\text { rho }\end{array}$} & \multirow[b]{2}{*}{ commitment } & \multirow[b]{2}{*}{$\begin{array}{l}\text { Correlation } \\
\text { Coefficient }\end{array}$} & \multirow{2}{*}{ 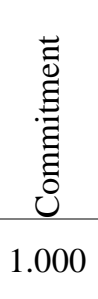 } & \multirow{2}{*}{$\frac{\stackrel{a}{\widetilde{U}}}{.671}$} \\
\hline & & & & \\
\hline & & Sig. (2-tailed) & . & .000 \\
\hline & & $\mathrm{N}$ & 100 & 100 \\
\hline & CSR & $\begin{array}{l}\text { Correlation } \\
\text { Coefficient }\end{array}$ & .671 & 1.000 \\
\hline & & Sig. (2-tailed) & .000 & . \\
\hline & & $\mathrm{N}$ & 100 & 100 \\
\hline
\end{tabular}

\section{Analysis}

From the above correlation matrix correlation between commitment of employees are positively correlated. So, corporate social responsibility of agro and organizational

accept the null hypothesis and reject the alternative hypothesis.

Null hypothesis: There is no significance difference between Age of the respondents and corporate social responsibility.

Null hypothesis: There is level of difference between Age of the respondents and corporate social responsibility.

Chi-Square Tests

\begin{tabular}{|l|l|l|l|}
\hline & Value & Df & $\begin{array}{l}\text { Asymp. Sig. (2- } \\
\text { sided) }\end{array}$ \\
\hline Pearson Chi-Square & $86.706(a)$ & 81 & .312 \\
\hline Likelihood Ratio & 94.691 & 81 & .142 \\
\hline $\begin{array}{l}\text { Linear-by-Linear } \\
\text { Association }\end{array}$ & 6.743 & 1 & .009 \\
\hline N of Valid Cases & 100 & & \\
\hline
\end{tabular}

Analysis

From the above chi-square p-value is less than alpha value. So, reject the null hypothesis. Therefore, there is significant difference between gender of respondents and organizational commitment.

Null hypothesis: There is no significant difference between Gender of the respondents and corporate social responsibility.

Null hypothesis: There is no significant difference between Gender of the respondents and corporate social responsibility.

Chi-Square Tests

\begin{tabular}{|l|l|l|l|}
\hline & Value & Df & $\begin{array}{l}\text { Asymp. Sig. (2- } \\
\text { sided) }\end{array}$ \\
\hline Pearson Chi-Square & $30.572(\mathrm{a})$ & 27 & .289 \\
\hline Likelihood Ratio & 39.646 & 27 & .055 \\
\hline $\begin{array}{l}\text { Linear-by-Linear } \\
\text { Association }\end{array}$ & .034 & 1 & .855 \\
\hline N of Valid Cases & 100 & & \\
\hline
\end{tabular}

\section{Analysis}

From the above chi-square p-value is more than alpha value. So, accept the null hypothesis. There is no significant difference between Gender of the respondents and corporate social responsibility.

Null hypothesis: There is no significant difference between Gender of the respondents and organizational commitment.

Null hypothesis: There is significant difference between Gender of the respondents and organizational commitment.

Chi-Square Tests

\begin{tabular}{|l|l|l|l|}
\hline & Value & df & $\begin{array}{l}\text { Asymp. Sig. } \\
\text { (2-sided) }\end{array}$ \\
\hline Pearson Chi-Square & $23.807(\mathrm{a})$ & 18 & .161 \\
\hline Likelihood Ratio & 29.145 & 18 & .047 \\
\hline $\begin{array}{l}\text { Linear-by-Linear } \\
\text { Association }\end{array}$ & 3.562 & 1 & .059 \\
\hline N of Valid Cases & 100 & & \\
\hline
\end{tabular}


Analysis

From the above chi-square p-value is less than alpha value. There is significant difference between Gender of the respondents and organizational commitment.

\section{FINDINGS}

The analysis mainly reveals the next facts.

1. $57 \%$ of the respondents will be male.

2. $49 \%$ of the respondents happen to be aged between 20 and 30.

3. Most of the respondents concur that they are proud to inform visitors to whom they serve.

4. Most of the respondents agree that the company they are serving is very vital for their existence and are very dependent on it.

5. The analysis shows that the business is qualified and in a position to accomplish its objective.

6. Most of the respondents concur that they possess a solid sense of belonging in the organization.

7. Most of the respondents concur that they feel just like part of a family in this organization.

8. Most of the respondents concur that their managers value the work they perform for them.

9. Most of the respondents concur that their accomplishments.

10. Most of the respondents concur that their firm does all it could to identify employees for outstanding performance.

11. Most of the respondents concur that their attempts are never overlooked by the company.

12. Most of the respondents concur that their company guidelines encourage the workers to build up their abilities and careers.

13. The analysis reveals that the business implements flexible plans to provide an excellent work life stability because of its employees.

14. The business supports employees who wish to acquire extra education.

15. Most of the respondents concur that being socially accountable is key to the firm.

16. The analysis shows that interpersonal responsibility of a company is vital to its long-term profitability.

17. The entire performance of an organization can be decided to a great extent by its commitment for social responsibility.

18. Social responsibility is crucial to the survival of a commercial enterprise.

\section{SUGGESTIONS}

1. The strong should provide staff with good teaching programs and assist them for higher education,

2. CSR should not be treated as only a mission declaration in corporate conferences; it must be the central little bit of a company's planning. The main element to a sustainable achievement is to activate the employees. It's important to describe to the personnel why looking after regional communities corporation appreciates them for the

and their setting represents such a strategic importance.

3. Businesses should improve their employee dedication including themselves in sociable activities for example, identifying requirements of the city and fulfilling them, doing work for better natural environment, involving in worker welfare, producing top quality products for clients and 184 .

4. Complying with government regulations and operating within legal ambience. Each one of these activities considerably and positively impacts employee determination with businesses and increases organizational performance.

5. The business provides staff members with proficient leadership, which has its impact on the workforce.

\section{CONCLUSION}

Recently the word corporate cultural responsibility (CSR) has gained prominence, both running a business and, in the press, to such an extent that it appears to have grown to be ubiquitous.

There are most likely multiple reasons for the interest directed at this phenomenon, not the least being the corporate excesses witnessed recently. Gaining full support from workers and making certain they are dedicated and motivated to obtaining company's objectives, locating problems and effecting complex online management.

CSR should not be treated as only a mission statement found in corporate conferences; it ought to be the central little bit of a company's approach planning. The main element to a sustainable accomplishment is to get the employees involved.

It is important to explain to the staff why looking after local communities and their setting is of such a strategic importance. These findings indicate that the administration should come up with beneficial CSR activities which will increase the brand value of the organization.

The email address details are also essential in the light of the elements of CSR, like financial responsibility and responsibility.

\section{REFERENCES}

1. Turker, D. (2009). How corporate social responsibility influences organizational commitment. Journal of Business Ethics, 89(2), 189-204.

2. Podsakoff, P. M., MacKenzie, S. B., Lee, J., \& Podsakoff, N. P. (2003). Common method biases in behavioural research: A critical review of the literature and recommended remedies. Journal of Applied Psychology, 88(5), 879-903.

3. Rettab, B., Brik, A. B., \& Mellahi, K. (2009). A study of management perceptions of the impact of corporate social responsibility on organizational performance in emerging economies: the case of Dubai. Journal of Business Ethics, 89, 371-390. http://dx.

4. Collier, Jane and Esteban, Rafael, Corporate Social Responsibility and Employee Commitment. Business Ethics: A European Review, Vol. 16, No. 1, pp. 19-33, January 2007.

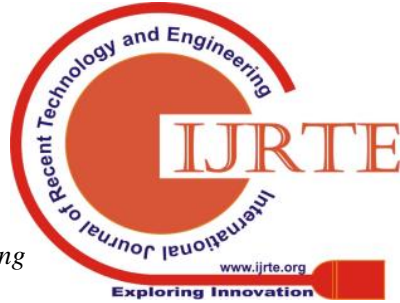




\section{A RESEARCH ON THE IMPACT OF CORPORATE SOCIAL RESPONSIBILITY (CSR) ON THE ORGANIZATIONAL COMMITMENT OF EMPLOYEES IN THE AGRO INDUSTRY}

5. Earl, T. B. W. (2004). Exploring the effects of corporate social performance on employees. Master dissertation, University of Alberta (Canada), p. 129.

6. Settoon, R. P., N. Bennett and R. C. Liden: 1996 -Social exchange in organizations: Perceived organizational support, leader-member exchange, and employee reciprocityll, Journal of Applied Psychology, 81(3), 219-227.

7. Peterson, D. K.: 2004, -The relationship between perceptions of corporate citizenship and organizational commitmentl, Business and Society, 43(3), 296-319.

8. Branco, M. C. \& Rodrigues, L. L. 2006. -Corporate Social Responsibility and Resource-Based Perspectives\|, Journal of Business Ethics, vol. 69, pp.111-132.

9. Sinnott, R. (2003). Attitudes and behavior of the electorate in the second referendum on the treaty of nice. Retrieved August 29, 2009, from http://www. ucd.ie/ dempart/ working papers/nice2. pdf

10. Petrick, J. A., and Scherer, R. F. (1993). "Competing Social Responsibility Values and the Functional Roles of Managers: Implications for Career and Employment Professionals." Journal of Managerial Psychology, Vol. 8(3), pp. 14-21.

11. Dutton, Jane E., Janet M. Duckerich., and Celia V. Harquail. (1994). -Organizational images and member identification. \| Administrative Science Quarterly, 39 (2), 239-263. 186

12. Alexander GJ, Buchholz RA (1978). Corporate social responsibility and stock market performance. Acad. Manage. J. 21:179-486

13. Cochran PL, Wood RA (1984). Corporate social responsibility and financial performance. Acad. Manage. J. 27(1): 42-56.

14. Stanwick PA, Stanwick SD (1998). The relationship between corporate social performance, organization size, financial performance and environmental performance: an empirical examination. J. Bus. Ethics, 17(2):195-204.

15. McWilliams A, Siegel D (2001). Corporate social responsibility: a theory of firm's perspective. Acad. Manag. Rev., 26(1):117-127.

16. Arx UV, Ziegler A (2008). The effects of CSR on stock performance: new evidence for USA and Europe. Economic Working Paper Series, Swiss Federal Institute of Technology Zurich.

17. Brinkman J, Peattie K (2008). Consumer ethics research: reframing the debate about consumption for good. Elec. J. Bus. Ethics Org. Stud., 13(1):22-31.

18. Ali I, Rehman KU, Yilmaz AK, Nazir S, Ali JF (2010). Effects of corporate social responsibility on consumer retention in cellular industry of Pakistan. Afr. J. Bus. Manag., 4(4):475-485.

19. Heslin PA, Achoa JD (2008). Understanding and developing strategic corporate social responsibility. Org. Dynamics. 27(2): 125-144.

20. Collier, Jane and Esteban, Rafael, Corporate Social Responsibility and Employee Commitment. Business Ethics: A European Review, Vol. 16, No. 1, pp. 19-33, January 2007.

21. Stawiski S, Deal JJ, Gentry W (2010). Employee's perceptions of corporate social responsibility: the implications for your organization. Quick View Leadership Series, Center for Creative Leadership, USA.

22. Wolfe, R. A., \& Putler, D. S. (2002). How tight are the ties that bind stakeholder groups? Organization Science, 13(1), 64-80.

23. Bridges, S., \& Harrison, J. K. (2003). Employee perceptions of stakeholder focus and commitment to the organization. Journal of Managerial Issues, 15(4), 498509.
24. Bhattacharya, C. B., \& Sen, S., \& Korschun, D. (2008). Using corporate social responsibility to win the war for talent. MIT Sloan Management Review, 49(2), 36-45. 